\title{
PENGETAHUAN MENENTUKAN DIAGNOSA KEPERAWATAN OLEH PERAWAT DALAM PROSES ASUHAN KEPERAWATAN
}

\author{
Pebi Septrian Sari \\ febi.septrian03@gmail.com
}

\section{LATAR BELAKANG}

Proses keperawatan diawali dari pengkajian, perawat melakukan pengkajian kepada pasien dimulai dari mengumpulkan data secara sistematis, status kesehatan pasien, dan masalah kesehatan yang dialami. Kemudian dilanjutkan dengan dilakukannya diagnosa keperawatan. Diagnosa keperawatan merupakan langkah kedua dari proses keperawatan. Proses keperawatan merupakan metode ilmiah yang dipakai dalam memberikan asuhan keperawatan yang professional. Diagnosa keperawatan adalah suatu pernyataan yng menjelaskan respons manusia (status kesehtan atau resiko perubahan pola) dari individu atau kelompok, dimana perawat secara akuntabilitasi dapat mengidentifikasi dan memberikan intervensi secara pasti untuk menjaga kesehatan, menurunkan, membatasi, mencegah dan megubah.

Diagnosa keperawatan juga menjadi masalah kesehatan aktual dan potensial dimana berdasarkan pendidikan dan pengalamannya. Seorang perawat harus mampu dan mempunyai kewenangan untuk memberikan asuhan keperawatan. Kewenangan tersebut dapat diterapkan berdasarkan standar praktik keperawatan dan kode etik keperawatan yang berlaku di Indonesia. Perawat dimana saja ia bertugas,mengahadapi klien dengan segala macam kasus, dan melayani klien pada semua tingkat usia juga harus menggunakan proses keperawatan. Perawat diharapkan memahami tentang konsep proses keperawatan dan mampu menerapkan serta menyusunkan dalam sebuah dokumen status kesehatan klien.

North American Nursing Diagnosis Association (NANDA) menyatakan bahwa diagnosis keperawatan adalah keputusan klinik mengenai respons individu (klien dan masyarakat) tentang masalah kesehatan aktual atau potensial sebagai dasar seleksi intervensi keperawatan untuk mencapai tujuan asuhan keperawatan sesuai dengan kewenangan perawat. Perawat mendiagnosis masalah kesehatan, menyatakan risiko, dan kesiapan promosi kesehatan. Perawat mendiagnosis masalah kesehatan, menyatakan risiko, dan kesiapan promosi kesehatan. Diagnosis berfokus-masalah tidak boleh dipandang lebih penting daripada diagnosis risiko. Kadang-kadang diagnosis risiko dapat menjadi diagnosis dengan prioritas tertinggi bagi pasien. Sebuah contoh mungkin pasien yang memiliki diagnosis keperawatan 
intoleran aktivitas, hambatan memori, kesiapan meningkatkan manajemen kesehatan, dan risiko jatuh, dan baru dirawat di fasilitas perawatan. Meskipun intoleran aktivitas dan hambatan memori adalah diagnosis berfokus-masalah, risiko jatuh pasien mungkin prioritas diagnosis nomor satu, terutama karena ia menyesuaikan dengan lingkungan baru.

Diagnosa keperawatan ditegakkan berdasarkan respon fisik, sosio-kultural, psikologis, dan spiritual klien terhadap masalah kesehatannya yang bersifat individual, sehingga diperlukan kemampuan berpikir kritis dalam proses diagnostik. Penegakkan diagnosa keperawatan harus didukung sekelompok data dasar yang didapatkan oleh perawat saat melakukan pengkajian. Kelompok data ini disebut batasan karakteristik. Batasan karakteristik adalah indikator klinis yang merupakan tanda dan gejala objektif atau subjektif atau faktor risiko yang mendukung adanya kategori diagnostik. Keakuratan indikator klinis ditentukan dengan kemunculan batasan karakteristik dan faktor yang berhubungan (etiologi) dari suatu diagnosa keperawatan.

\section{METODE}

Metode yang digunakan pada penulisan ini menggunakan metode literature review atau studi literatur dengan cara menganalisis dan melakukan eksplorasi terhadap bahan kajian yang berfokus pada pokok pembahasan yang berhubungan dengan diagnosa keperawatan yang dilakukan oleh perawat. Penulisan ini menggunakan sumber referensi berupa jurnal, artikel, textbook, e-book yang relevan dan terpercaya. Jurnal yang dipakai merupakan jurnal yang diterbitkan dalam 10 tahun terakhir.

\section{HASIL}

Hasil dari melakukan proses literatur review terhadap sumber telah didapatkan pengertian diagnosa keperawatan, tujuan diagnosa keperawatan dan pengetahuan perawat dalam melakukan diagnosa keperawatan. Di temukan bahwa perawat dalam melakukan diagnosa keperawatan masih cukup tinggi dengan tidak merumuskan diagnosa keperawatan aktual Menurut peneliti tidak dirumuskannya diagnosa keperawatan aktual karena perawat pelaksana belum mampu menganalisa data dan mengidentifikasi masalah pasien berdasarkan respon pasien yang seharusnya dapat dilihat pada pengkajian yang telah dilakukan. Diagnosa keperawatan merupakan kesimpulan masalah kesehatan yang dialami pasien. diagnosa keperawatan adalah masalah yang nyata (aktual) ataupun masalah potensial yang mungkin 
dialami pasien. Menurut PPNI (2010) komponen diagnosis keperawatan terdiri dari masalah $(\mathrm{P})$, gejala/tanda $(\mathrm{S})$ atau terdiri dari masalah dengan penyebab (PE).

\section{PEMBAHASAN}

Standar praktik keperawatan profesional di Indonesia telah dijabarkan oleh Persatuan Perawat Nasional Indonesia (PPNI) pada tahun 2000. Standar tersebut mengacu pada proses keperawatan yang terdiri atas lima tahap, yaitu pengkajian, diagnosis, perencanaan, implementasi, dan evaluasi (Nursalam 2008). Proses keperawatan adalah satu pendekatan untuk pemecahan masalah yang memampukan perawat untuk mengatur dan memberikan asuhan keperawatan. penggunaan proses keperawatan sebagai metode ilmiah bagi seorang perawat dalam memecahkan masalah klien serta implementasi proses keperawatan secara berkesinambungan, terstruktur melalui penggunaan form keperawatan yang memfasilitasi penggunaan proses keperawatan, serta diskusi kasus yang mengadopsi proses keperawatan dalam memecahkan masalah klien.

Diagnosis Keperawatan merupakan keputusan klinik tentang respon individu, keluarga dan masyarakat tentang masalah kesehatan aktual atau potensial, dimana berdasarkan pendidikan dan pengalamannya, perawat secara akuntabilitas dapat mengidentifikasi dan memberikan intervensi secara pasti untuk menjaga, menurunkan, membatasi, mencegah dan merubah status kesehatan klien.

Penegakan diagnosis keperawatan sebagai salah satu komponen standar asuhan keperawatan perlu dilaksanakan dengan baik sebagaimana yang diamanahkan dalam undangundang No.38 tahun 2014 tantang keperawatan pada pasal 30 bahwa dalam menjalankan tugas sebagai pemberi asuhan keperawatan, perawat berwenang menetapkan diagnosis keperawatan. Hal ini menegaskan wewenang perawat sebagai penegak diagnosis yang harus memiliki kemampuan diagnosis yang baik sebagai dasar mengembangkan rencana intervensi keperawatan dalam rangka mencapai peningkatan, pencegahan dan penyembuhan serta pemulihan kesehatan klien. Diagnosis keperawatan telah dibuat oleh perawat di bawah kewenangan perawat, diagnosis keperawatan aktual.

Diagnosa keperawatan actual, yaitu diagnose keperawatan yang menjelaskan masalah kesehatan yang nyata terjadi dan benar-benar factual sesuai dengan data klinis yang diperoleh.Syarat untuk menegakkan diagnose keperawatan actual adalah terpenuhinya unsur PES. Komponen diagnosa aktual : 


\section{Label Diagnosis.}

Memberikan sebuah nama untuk sebuah diagnosis yang menunjukkan fokus diagnosis dan penilaian keperawatan. Label ini merupakan istilah atau frase singkat yang menunjukkan sebuah pola isyarat.

2. Batasan Karekteristik.

Sebagai manifestasi diagnosis berfokus-masalah, promosi kesehatan atau sindrom.

\section{Faktor Risiko.}

Faktor lingkungan dan fisiologis, psikososial, genetik, atau elemen kimia yang meningkatkan kerentanan individu, keluarga, kelompok, atau komunitas pada kejadian yang tidak sehat.

4. Faktor yang Berhubungan.

Faktor yang menunjukkan beberapa jenis pola hubungan dengan diagnosis keperawatan. Hanya diagnosis keperawatan berfokus-masalah dan sindrom berfokus-masalah harus memiliki faktor yang berhubungan.

5. Populasi Berisiko.

Kelompok individu yang memiliki karakteristik sama yang menyebabkan setap anggotanya rentan terhadap respons manusia tertentu. Karakteristik ini tidak dapat diubah oleh perawat profesional.

6. Kondisi Terkait.

Diagnosis medis, cedera, prosedur, alat medis, tau agens farmaseutika. Kondisi ini tidak dapat dirubah secara mandiri oleh perawat profesional.

Untuk dapat merumuskan diagnosa keperawatan dibutuhkan kemampuan analisis yang tinggi sehingga diperlukan sumber daya manusia yang capable dan mempunyai motivasi kuat untuk maju serta berpandangan maju (futuristic). Pada status pasien yang telah dikaji terlihat bahwa perawat hanya memilih saja diagnosa keperawatan yang telah disediakan di bagian samping format pengkajian. Hal ini memang lebih memudahkan perawat akan tetapi juga dapat menyebabkan perawat menjadi malas dan kurang inisiatif untuk menganalisa data lalu merumuskan diagnosa keperawatan sendiri apabila ditemukan data yang berbeda. 
Faktor yang menyebabkan ketidakakuratan kode diagnosis diantaranya adalah kesalahan dalam menuliskan kode. Pada prakteknya, perawat sering mengalami kesulitan dalam melaksanakan asuhan keperawatan. Sering sekali perawat kesulitan dalam hal menetapkan diagnosa keperawatan yang tepat bagi pasien. Pada kasus yang lain, data dikumpulkan tanpa menyadari mengenai apa diagnosanya. Perawat juga mengumpulkan data yang mempunyai relevansi yang rendah dengan diagnosa keperawatan tertentu.

Fungsi perawat dalam melakukan kegiatan yaitu membantu individu baik yang sehat maupun yang sakit, dari lahir hingga meninggal, membantu melaksanakan aktivitas sehari-hari secara mandiri, dengan menggunakan kekuatan, kemauan, atau pengetahuan yang dimiliki. Masalah utama kinerja perawat dalam pelayanan keperawatan adalah kurangnya perawat yang berpendidikan tinggi, kemampuan yang tidak memadai. Perawatan yang profesional dicerminkan dalam pendokumentasian yang profesional, yang membuktikan tentang apa yang dilakukan oleh perawat dan secara efektif menggambarkan status dan kemajuan klien. Informasi yang menggambarkan masalah klien atau diagnosis keperawatan kemudian mengarah pada pemberian asuhan keperawatan untuk memilih suatu rencana perawatan yang sesuai dengan terapi keperawatan (Potter \& Perry 2009).

Pelayanan kesehatan diberikan oleh berbagai jenis propesi kesehatan, termasuk perawat, dokter, dan fisioterapi. Hal ini sangat berlaku di rumah sakit serta tatanan pelayanan kesehatan lainnya secara kontinum (mis, klinik, perawatan dirumah, perawatan jangka panjang, lembaga bebasis-agama, penjara). Setiap disiplin profesi kesehatan memiliki keunikan kerangka pengetahuan untuk perawatan klien. Setiap profesi kesehatan memiliki cara untuk menggambarkan "Apa" yang profesi pahami dan "Bagaimana” bertindak berdasarkan apa yang mereka pahami. Setiap profesi memiliki bahasa yang biasa digunakan untuk menggambarkan dan memberi kode pengetahuan mereka. Dokter mengobati penyakit dan menggunakan taksonomi Klasifikasi Penyakit Internasional (Internasional Classification of Disease, ICD) untuk mewakili dan kode masalah medis yang mereka obati.

Proses keperawatan meliputi pengkajian, diagnosis keperawatan, perencanaan, penyusunan kriteria hasil, tindakan, dan evaluasi. Perawat mengggunakan pengkajian dan penilaian klinis untuk merumuskan hipotesis, atau penjelasan tentang penyajian masalah aktual atau potensial, resiko dan/atau peluang promosi kesehatan. Semua langkah-langkah ini membutuhkan pengetahuan tentang konsep-konsep yang mendasari ilmu keperawatan sebelum pola diidentifikasi sesuai data klinis atau penetapan diagnosis yang akurat. 
Suatu diagnosis keperawatan adalah penilaian klinis tentang respons manusia terhadap gangguan kesehatan/proses kehidupan, atau kerentanan terhadap respons tersebut dari seorang individu, keluarga, kelompok, atau komunitas. Suatu diagnosis keperawatan biasanya berisi 2 bagian : (1) deskriptor atau pengubahan dan (2) fokus diagnosis, atau konsep kunci dari diagnosis. Ada beberapa pengecualian ketika diagnosis keperawatan hanya satu kata seperti ansietas, kontipasi, keletihan, dan mual. Pada diagnosis tersebut, pengubahan dan fokus bersesuaian dalam satu kondisi. Perawat mendiagnosis masalah kesehatan, menyatakan resiko, dan kesiapan promosi kesehatan. Diagnosis keperawatan digunakan untuk mengidentifikasi hasil yang diharapkan dari perawatan dan merencanakan tindakkan keperawatan yang spesifik secara berurutan.

Setiap diagnosis keperawatan memiliki label dan definisi yang jelas. Hal ini penting untuk menyatakan bahwa jika hanya memiliki label atau daftar abel tidak mencukupi. Sangat penting bahwa perawt mengetahui definisi diagnosis yang paling sering mereka gunakan. Selain itu, mereka perlu mengetahui "indicator diagnostic" data yang digunakan untuk mendiagnosis dan untuk membedakan satu diagnosis dari yang lain.

Komponen diagnosa keperawatan:

Komponen - komponen dalam pernyataan diagnosis keperawatan meliputi masalah (Problem), penyebab (etiologi), dan data (sign and symptom). Untuk memeudahkannya, disingkat dengan PES.

1.Masalah (problem). Diagnosis keperawatan merupakan perntayaan yang menggambarkan perubahan status kesehatan klien.

2.Penyebab (etiology). Pernyataan etiologi mencerminkan penyebab dari masalah kesehatan klien yang memberi arah bagi terapi keperawatan. Etiologi tersebut dapat terkait dengan aspek patofisiologi, psikososial, tingkahlaku, perubahan situasional, gaya hidup, usia perkembangan, juga faktor budaya dan lingkungan.

3.Data (sign and symptom). Data diperoleh selama tahap pengkajian sebagai bukti adanya masalah kesehatan pada klien. Data merupakan informasi yang diperlukn untuk merumuskan diagnosis keperawatan.

Perawat sering sekali kesulitan dalam menentukan diagnosis keperawatan spesifik yang dialami oleh pasien. Hal ini mungkin karena pengkajian keperawatan yang tidak terstruktur 
dengan baik. Pengalaman menunjukkan bahwa pengkajian yang dilakukan oleh perawat tidak mempunyai urutan yang runut dan terkait dengan diagnosis keperawatan.Sering terjadi perawat mempunyai data tertentu tetapi kebingungan untuk menentukan data tersebut mendukung diagnosis keperawatan yang mana. Atau sebaliknya perawat mempunyai prediksi pasien mempunyai diagnosis tertentu tetapi tidak tahu data apa yang perlu dikaji untuk mendukung diagnosis tersebut muncul.

Adapun persyaratan dari diagnosa keperawatan ialah perumusan wajib jelas dan singkat dari respons klien terhadap situasi yang dihadapi, spesifik dan akurat, memberikan arahan pada askep, bisa dikerjakan oleh perawat dan mencerminkan keadaan kesehatan klien.

\section{PENUTUP}

Dalam memberi asuhan keperawatan perawat harus memahami proses keperawatan. Proses keperawatan merupakan tahap awal yang harus dilakukan perawat. Dalam proses keperawatan terdapat tahap diagnosa keperawatan. perawat secara akuntabilitas dapat mengidentifikasi dan memberikan intervensi secara pasti untuk menjaga, menurunkan, membatasi, mencegah dan merubah status kesehatan klien. Fungsi diagnosa keperawatan yaitu untuk mengidentifikasi, memfokuskan, dan memecahkan masalah keperawatan klien secara spesifik.

Diagnosis keperawatan ditetapkan berdasarkan analisis dan interpretasi data yang diperoleh dari pengkajian keperawatan klien. Diagnosis keperawatan memberikan gambaran tentang masalah atau status kesehatan klien yang nyata (aktual) dan kemungkinan akan terjadi, dimana pemecahannya dapat dilakukan dalam batas wewenang perawat. Adapun komponen dalam diagnosis keperawatan Masalah (problem), Penyebab (etiology), dan Data (sign and symptom). Dan untuk meningkatkan pengetahuan perawat mengenai diagnosa keperawatan rumah sakit disarankan untuk mengadakan seminar atau pelatihan yang dapat meningkatkan keakuratan dokumentasi.

\section{DAFTAR PUSTAKA}

Nursalam. (2008). Konsep dan Penerapat Metodelogi Penelitian Ilmu Keperawatan (ed. 2). Jakarta : Salemba Medika.

NANDA. 2018. Diagnosis Keperawatan : Definisi dan Klasifikasi 2018-2020. (T. H. Herdman \& S. Kamitsuru, Eds 11) 
Ransan, Y., Ichsan, B \& Herman. 2018. Faktor - Faktor Yang Mepmpengaruhi Penegakan Standar Diagnosa Keperawatan Di Rumah Sakit Umum Daerah Soedarso Pontianak. Jurnal Keperawatan dan Ilmu Kesehatan Tanjung Pura. Vol 1(1)

Supratti \& Ashriady. 2016. Pendokumentasian Standar Asuhan Keperawatan Di Rumah Sakit Umum Daerah Mamuju Indonesia. Jurnal Kesehatan Manarang. Vol 2(1)

Apriyani, H. 2015. Identifikasi Diagnosis Keperawatan Pada Pasien Di Ruang Paru Sebuah Rumah Sakit. Jurnal Keperawatan. Vol 9(1). 107-111

Sugiyati, S. 2014. Hubungan Pengetahuan Perawat Dalam Dokumentasi Keperawatan Dengan Pelaksanaannya Di Rawat Inap RSI Kendal. Prosiding Konferensi Nasional II PPNI

Novieastari, E. 2013. Diagnosis Keperawatan Sejahtera. Jurnal Keperawatan Indonesia. Vol $7(2)$

Mangole, J, E. Dkk. 2015. Hubungan Perilaku Perawat Dengan Pendokumentasian Asuhan Keperawatan Di Cardiovascular And Brain Center RSUP. DR.R.D. Kandou Manado. Jurnal Keperawatan. Vol 3(2).

Koerniawan , D., Daeli, E, N \& Srimiyati. 2020. Aplikasi Standar Proses Keperawatan : Diagnosis, Outcome, dan Intervensi Pada Asuhan Keperawatan. Jurnal Keperawatan Silampari. Vol 3 (2)

Simamora, R. H., Bukit, E., Purba, J. M., \& Siahaan, J. 2017. Penguatan kinerja perawat dalam pemberian asuhan keperawatan melalui pelatihan ronde keperawatan di rumah sakit royal prima medan. Jurnal pengabdian kepada masyarakat, 23(2), 300-304.

Simamora, R. H. (2019). Socialization of Information Technology Utilization and Knowledge of Information System Effectiveness at Hospital Nurses in Medan, North Sumatra. Editorial Preface From the Desk of Managing Editor..., 10(9)

Cikwanto \& Nupiyanti. 2018 .Pengembangan Instrumen Penegakkan Diagnosis Keperawatan pada Pasien Confestive heart Failure(CHF) Berbasis Standar Diagnosis Keperwatan Indonesia(SDKI). Jurnal Keperawatan AISYIYAYAH.Vol5 (1).Hal 51-63 